\title{
PRINTED PUBLICATIONS OF RUSSIAN TECHNICAL SOCIETY BRANCHES AS A SOURCE OF HISTORY OF SCIENCE AND TECHNOLOGY
}

\section{Kushlakova Nadiya ${ }^{1}$ Oleshko Petro ${ }^{2}$}

DOI: https://doi.org/10.30525/978-9934-571-78-7_41

Abstract. The second half of the XIX century was a period of active development of science and technology in the Russian Empire, the characteristic feature of which was the formation of various public and scientific associations and organizations which were set up to consolidate advanced scientific and technical thought and the dissemination and promotion of scientific knowledge. After the reforms of the 1860s the various scholarly societies appeared on the territory of the Russian Empire at a rapid pace. The scientific and technical societies, which were created to promote the development of a particular field of scientific and technical knowledge, took a prominent place among such a large number of scientific and technical societies. The most famous scientific and technical society, which united representatives of the industrial bourgeoisie and advanced technical intelligentsia in its circle, is considered the Imperial Russian Technical Society (IRTS). It was created in St. Petersburg on the initiative of scientists and engineers in 1866. The diverse activities of the Russian Technical Society and its branches have significant gaps to date and require profound research in each individual case. As a subject of the research we have identified a separate direction of the activity of the branches, namely the information and publishing activity on the example of Kharkiv and Katerynoslavsk branches of the RTS. The purpose of our research is to carry out a detailed analysis of the various areas of publishing activities of the determined RTS branches, to find out their contribution to the development of engineering and scientific thought and the consolidation of technical

\footnotetext{
${ }^{1}$ Doctor of Historical Sciences, Head of the Department of Social and Humanities and Fundamental Courses, Zahidnodonbaskyi Institute of IAPM, Ukraine

${ }^{2}$ Candidate of Historical Sciences, Rector,

Volyn Institute of Postgraduate Pedagogical Education, Ukraine

(C) Kushlakova Nadiya, Oleshko Petro
} 
intelligentsia in Ukraine. The content of the information and publishing activity of engineering and scientific societies, the printed organs of which were the only local source for obtaining the necessary information from various fields of technical knowledge at times, was determined by the professional requests of the engineering and technical community of the industrial complex of the studied region and covered a wide range of scientific and technical and socio-economic information. The latter has become an important factor in creating an effective system of communication and information communications of the technical intelligentsia. The main types of printed products of public scientific and technical associations of the region were periodicals and technical literature. Taking into account the lack and sometimes the total absence of necessary information and special professional literature of scientific and technical publications the societies served as professional technical journals. The study has implemented the analysis of special journals «Schetovodstvo i hozjajstvo» and «Tjazhelee vozduha» issued by Kharkiv branch of IRTS, their outstanding significance for forming new directions of scientific and practical accounting and dissemination and popularization of aviation knowledge has been proved. The publication of separate scientific imprints, the works of the members of the societies, the teaching aids for evening class listeners (KhB IRTS), reviews of the technical literature was widely practiced. The study does not deplete the raised problem in the activities of public scientific and technical assossiations, but only covers certain areas of activity, leaving a considerable space for further scientific research.

\section{Introduction}

The history of the creation and activity of public scientific and technical associations in the territory of the Russian Empire dates back to the second half of the nineteenth century, when the active development of industry in the state required the unification of representatives of various branches of scientific knowledge. The considerable attention to the issues of emergence of the first scientific societies in general and scientific and technical, in particular, has been given in the work of O. Sobolieva [1]. The first work devoted to the history of the creation of scientific and technical societies was the study of M. Filipov, in which the author considered the society of technicians and engineers of St. Petersburg in retrospect, and also revealed the process of creation, opening and activity of the first Russian Technical 


\section{Chapter «Historical sciences»}

Society (RTS) [2]. At present time not much is known about the historical intelligence devoted to the process of occurrence and separate areas of activity of the branches of the Russian Technical Society. Therefore, the subject of our study is the publishing activity of the branches of the Russian Technical Society, which were created in industrialized regions of Ukraine (in particular, in Kharkiv and Katerynoslavsk). The results of research are presented in this study. In doing so, we aimed to carry out a detailed analysis of the various areas of publishing activity of the Katerynoslavsk and Kharkiv branches of RTS. In the process of scientific enquiry the following principles of scientific research have been used: objectivity, historicity, scientific approach, multifactor, systematic and comprehensive analysis of the problem, specificity, reliance on historical sources and the principle of historiographical tradition. In accordance with the goal and subject and based on the laws of logic and the systematic approach to the objects, which were studied, a set of research methods has been determined. Moreover, the general scientific (empirical and theoretical), general historical, special historical and borrowed from other sciences methods have been used.

\section{2. «Zapiski» - printed organs of IRTS branches}

The main purpose of the Russian Technical Society activities was to promote the development of technology and the technical industry in the country. All branches of IRTS had the similar aim, respectively. One of the main conditions for achieving the determined purpose was the organization of information and publishing activity, which was reflected in both the Statute of the IRTS and in Instructions of its departments - «the means to achieve this goal are supposed... dissemination of theoretical and practical information through periodicals and other publications» [3, p. 107]. That was initiated by the central branch of IRTS, which had been published its own journal «Zapiski Russkogo tehnicheskogo obshhestva» since 1867. It went out every month until 1869, then for 15 years the periodicity of the journal's publication decreased to 6 books per year, and from 1885 the edition of 10-12 issues was renewed annually. The structure of the journal was divided into four sections: minutes of meetings of the IRTS; original articles of mostly technical content; review of technical findings and inventions; description of privileges (author's certificates and patents) on domestic and foreign inventions.

Like the IRTS most of the departments tried to establish their own print body and set up a publishing business from the first year of their activity. 
Taking into account the funding provided from the society's own budget the organization of the periodical was rather uneasy. From the departments operating on the territory of modern Ukraine, their own «Zapiski» were issued by the Kyiv Branch from 1871, Kharkiv - from 1881, Odessa - from 1885, Katerynoslavsk - from 1902, Mykolaiv - from 1904.

The decision to publish «Zapiski Har'kovskogo otdelenija Imperatorskogo Russkogo tehnicheskogo obshhestva», initiated by the Council in the person of M. Avdakov, was adopted unanimously at the meeting of the fifth general meeting of the company on November 22, 1880. In favor of this decision, Mykola Stepanovych put forward the following arguments: «1) At the disposal of the Council there is already quite sufficient material for the publication of several volumes of the society's notes, including in each volume from 2 to 3 already made reports of members of the society, as well as magazines of meetings of both society and the Council. 2) The publication of Notes of a society will inevitably entail an exchange with similar publications of other societies, which is highly desirable, will be the beginning of the technical library of society. 3)... for the printing of the Notes of the society in the amount of 500 copies, from 10 to 12 sheets in each, according to the information provided, will cost the society from 300 to 3500 r. s.; and the society has a fair amount of money. 4) In order to cheapen the publication, the Council finds it possible to allow "Zapiski» the printing of private advertisements at the price set by the Council» [4, c. 131]. Thus, «Zapiski Har'kovskogo otdelenija Imperatorskogo Russkogo tehnicheskogo obshhestva» began to go out and it was allocated from the budget of the company 350 rubles for its publication from 1881 .

After the publication of the first issue of the magazine (costs were 300 rubles), which contained articles prepared on the basis of the reports of members of the society and made at the general meeting, minutes of the meetings of the Council and general meetings, the part of the Council and announcements made at the general meeting of the society, the program and volume of «Zapiski» were discussed and approved on January 12,1882 [4, p. 144].

Not all plans of the society were destined to be fulfilled, because life made its adjustments: the program of «Zapiski» mainly consisted of articles prepared on the basis of reports of members of the society, made at the general meetings, minutes of meetings of the Council and general meetings, the composition of the Council and the list of members of the society, annual reports on society activities, announcements, etc. The volume of the 
magazine was arbitrary, and the price varied from 1 ruble up to 4 rubles per a year. Already in 1884, the Council of the society, because of the difficult financial situation of the department, which inhibited the publication of the magazine, filed a petition to the central branch of the Russian Technical Society to receive a grant of 1,000 rubles exclusively on the publication of «Zapiski» [5]. The Kharkiv branch in response was obliged to send 100 copies of each issue of the magazine to RTS. This petition was signed by all members presented at the meeting of the general member meeting on March 31, 1884, but obviously it was not resolved positively, because no facts regarding the mentioned question were found in the financial statements or in the minutes of the meetings of the society for the current and subsequent years. Most likely, the reason was that RTS was not in the best financial condition during that period, as evidenced, for example, it was due the interruption of the periodicity of the release of «Zapiski RTS», which was discussed above. However, the response to the petition presumably had been a letter from the secretary of the RTS P. Andreev with the proposal that all reports and protocols of the Kharkiv branch could be printed in «Zapiski IRTS», which was published at the Council meeting on April 20, 1885, namely: «Editorial..., bearing in mind that the «Zapiski Obshhestva» should not serve as the organ of only its St. Petersburg branch, but is a significant part of the non-resident branches, having no organs or difficulties, for various reasons, to print reports and records on their activities, has the honor to propose to the Kharkiv Council branch send those reports to "Zapiski» for publication, which, in the opinion of the Council, deserve to be printed...» [6, p. 68]. The decision of the Council was unanimous and unpromising - P. Andreiev was denied, because «in exchange for "Zapiski» it (KhB IRTS - aut.) receives lots of periodicals, extremely necessary for it. The printing of all reports and protocols in the central notes would deprive the Kharkiv branch of the independence which it acquired» [6, p. 9]. That is, the members of the KhB RTS clearly imagined which communication and information links were provided by an independent periodical body and were not about to abandon it.

The periodicity of «Zapiski KhB RTS» and its amount depended on several factors: first, as noted above - «by the accumulation of material»; second, by the availability of sufficient resources, what was discussed in the previous section. The study showed these factors equally influenced the regularity of the publication of «Zapiski», and the first negative facts were 
already evident in 1885-1886, which is reflected in the report for the relevant period: «The shortage of material means of our branch, unfortunately, deprives the Council's opportunity to publish regular Zapiski regularly within the strictly defined terms... annually in the amount of 4 releases, but to do this kind of resolution was not provided any opportunity due to lack of funds, especially at the shortage of literary material (reports)» [7, p. 24-25]. So, the magazine was published not regularly: during 1881-1900 there were 1 to 4 issues a year out of print (in 1890-1891 the edition of the magazine was temporarily suspended), from 1901 to 1904 the magazine did not go out at all, in 1905 the publication was resumed and three issues were published, in 1907 it was only one issue, from January to June 1908 three issues of the magazine were published. However, even in the most difficult, from the point of view of financing, the period of the Kharkiv branch it was still not quite ceased its publishing activities - in 1904, the society has prepared for publication two books (II-nd and III-rd parts of work of a mining engineer K. Milkowskyi «Provolochnyj kanat v teorii i gornoj praktike»), which was published as two unnumbered issues of «Zapiski» and make a bibliographic rarity nowadays. The first part of this scientific exploration was printed in «Zapiski» after the announcement on the General meeting of the society in 1898 [8]. It is interesting that during that period the mining engineer K. Milkowskyi worked in corporate Imperial Mining Academy in Leoben (Duchy of Styria, Austria). After approval of the new Charter of this institution in 1874 the lectureres of the Imperial Mining Academy were equated to the rank of professors of higher technical schools. That fact once again evidenced the popularity of the magazine «Zapiski KB IRTS « and its high professional level and geography of distribution.

The publishing activity of the Katerynoslavsk Branch of the Imperial Russian Technical Society, which managed to organize the regular publishing of 6 issues of their «Zapiski» per a year, was more successful. As proven by the research, KB IRTS fully resumed its activity in 1901, and since 1902 began the publication of its own magazine. The structure of the first issue was clearly devided into three parts: 1) formal part (information on the activities of the society during the past year); 2) the informal part (the texts of the reports made at the meetings of the society (of V. Burdakov, I. Tykhonov); 3) the bibliography [9, p. 472].

Over the next two years, 6 issues of magazines were published each year, in which reports and other works of the members of the society 
were posted, materials on the current activities of the KB IRTO (minutes of meetings, reports), bibliography or a review of periodical foreign and domestic editions, various announcements. Since 1905 (there were dual issues) and until 1913 the Katerynoslavsk branch was established the printing of 12 issues annually, the information in which was placed in sections, which varied depending on the taken to a set of materials. Thus, No.1-2 in 1905 was consisted of 4 sections - 1) metallurgical, 2) mining, 3) railway, 4) various and bibliography; and, for example, No. 11-12 consisted of two sections - official and metallurgical. Such changes to a better were made due to the special decision taken at the meeting of the Society Council on December 9, 1904, where, after discussion of the program of the next issue of the magazine, the members of the council decided: 1) to request O.Terpigoriev to be an editor of «Zapiski» 2) to expand and diversify the magazine in such a way that it could satisfy the interests of all members of the society [10, p. 1-22]. At the general meeting of the KB IRTS on January 13,1905 O. Terpigoriev made a presentation on his vision of the contents and structure of the magazine, offering materials in four sections (machine building, railways, mining and metallurgy).

The content and periodicity of the publishing of «Zapiski» changed with the beginning of the First World War: the magazine was published in duplicate releases - in 1914 six numbers, in 1915 - 12, in 1916 - 9. A general copy of the "Zapiski KB IRTS», as well the number of issuies varied and sometimes made up to 400 copies a year, but it did not always satisfy the readers' demand. Taking into account a relatively small number of members of the society and its so-called «peripherality», this fact indicates the high demand of this printed publication, its popularity and wide range of distribution.

An editor or editorial committee, which was responsible for the content and quality of the magazine, had an important role in the publishing activity of any public and scientific association. In the Kharkiv branch of the IRTS the editorial committee did not exist as a separate subdivision, the Council was responsible for publishing the magazine. Only in 1907, when it was decided to strengthen the activities of the KhB IRTS, one of the means to achieve this goal was the decision to establish an Editorial Committee led by $\mathrm{M}$ von Dietmar as the head of the department. The first composition of the Editorial Committee in 1902 was as follows: K. Volodkevych, S. Hrabovyi, K. Neimaiier, S. Stanovskyi, V. Stulhynskyi, O. Maltsev, I. Tykhonov, M. Urzhumtsev, L. Yachevskyi. 
The editorial boards of «Zapiski» of both societies were represented by well-known specialists from various fields of scientific and technical knowledge, which provided for the preparation and publication of interesting and high-quality magaziness, which initially planned to publish articles of a purely scientific nature. Nevertheless, during the meetings there were often reports of popular science nature, and the desire to expand the readership forced publishers to place popular science articles on their pages of «Zapiski». O. Terpygoriev, the editor of «Zapiski KB IRTS», remarked: «Our magazine may contain reports and articles of a more or less scientific character; articles and notes describing practical questions of technology; articles on technical issues and bibliography» [11, p. 26]. That is why we meet scientific articles, as well as works of a cognitive nature on popular topics in the same issue of the magazine.

\section{Print products of IRTS branches}

The publishing activity of IRTS departments was not limited to the publication of «Zapiski», a significant part of the print products was made up of individual imprints of the members of the society, the books that were published as annexes to the individual issues of the magazine, activity reports, lists of members, programs of courses, schools and other separate units of society, materials about their activities, etc. Thus, the Kharkiv branch of IRTS, together with the issue of the magazine number, printed individual reports (in 50 copies) in each issue, in favor of the author. There were also the publications of various brochures: a catalog for the AllOdessa Exhibition (Donetsk branch) (1884); A. Chirikov's report on the participation of the society in the exhibition (1885); catalog to the Kharkiv Agricultural Exhibition (1887), etc. The Katerynoslavsk branch published separate articles on the most important topics: «Chtenija po mehanike» [12], «Chtenija po fizike» [13], «Zhelezo-betonnye sooruzhenija Ekaterininskoj zh. d.» [14], «Vodosnabzhenie st. Sinel'nikovo Ekaterininskoj zh. d. i st. Sinel'nikovo K.-H.-Sevastopol'skoj zh. d. iz r. Dnepra»[15], «Ustrojstvo i jekspluatacija polej oroshenija g. Odessy, g. Kieva, g. Moskvy» [16], «K voprosu o mehanicheskoj ochistke stochnyh vod i spuske ih v reku Dnepr po proektu P. F. Gorbacheva o kanalizacii g. Ekaterinoslava» [17].

In the list above, the attention is drawn to the first two books, which are examples of educational literature, which were produced by scientific and technical societies for their educational institutions. So, the Katerynoslavsk 


\section{Chapter «Historical sciences»}

branch of IRTS, having opened the evening courses for workers, began to select textbooks for the educational process. It turned out that the existing educational literature on many disciplines was generally not suitable for training workers and did not correspond to the level of their preparedness, therefore, «to cope with existing textbooks... these people can not: textbooks are not composed for them» [18, p. 11]. It was these circumstances that forced the Katerynoslavsk branch to begin publishing textbooks. The active member of the department, the director of the Katerynoslavsk railway technical school V. Galytskyi, who taught physics and mechanics, prepared the mentioned above lectures for publication. In addition to the obtainable teaching language, the textbooks were also available from a financial point of view, because their price was 30 kopecks for a book, so they were sold in a kiosk at evening courses for workers. The evidence of the popularity of the educational literature was the fact that books at a cost of 400 rubles were sold through the kiosk only in the first half of 1907 [19, p. 47]. The experience of Katerynoslavsk branch in publishing educational literature was almost the only one among the branches of the Russian Technical Society.

In addition to the aforementioned, some of the prints of the magazine in the period 1909-1912 were published under the title « Uspyekhi prokatnogo dyela» (compiled by A. Rodzevich-Belevich), which later came out of print as an independent publication, and Anton Fabianovich Rodzevich-Belevich became the editor and publisher of this magazine. In the author's previous words to the first independent yearbook he wrote: «Since 1907 reviews of the technical successes of the rolling mill were compiled by me annually.

The first review: "The successes of the rolling mill in 1907» was published in "News of the technique and industry», four subsequent reviews: in 1908, 1909, 1910 and 1911 - in «Zapiski Ekaterinoslavskogo otdelenija I.R. Tehn. O-va».

The volume of reviews that grows from year to year does not allow me to use the longer hospitality of the last magazine, and this review, in 1912, I release as an independent yearbook» [20].

\section{Specialized magazines}

In addition to the publication of "Zapiski», brochures of catalogs and books in the branched of IRTS, there were attempts made to establish publishing of specialized periodicals. Thus, the Kharkiv branch of IRTS began publishing two magazines in the early XX century: «Schetovodstvo 
i hozjajstvo» - the body of the Accountig Archival Department and «Tjazhelee vozduha» - a printed body of the Aeronautic Department. The first magazine was focused primarily on accountants and was supposed to deal with the history, theory and practice of accounting, teaching accounting and commercial life in general. The second magazine although was specialized, but had popular science features and could therefore be of interest to the general public. Based on the uniqueness of these editions we consider it necessary to view them in detail.

The post-reform era in the Russian Empire is notable for the development of many branches of the national economy. At factories and plants, large and small enterprises, in any agricultural or manufacturing industry there was an urgent need for specially trained specialists. On the one hand, to solve this problem there were no professionally oriented educational institutions of different levels, and on the other hand - special literature (not only textbooks and manuals, but even periodicals). In order to disseminate the knowledge and achievements of science and technology in one or another field of scientific knowledge, the publishing business of the corresponding professional direction began to develop.

Not an exception in this situation the accounting was.There were practically no trained and educated professionals in this specialty. On the territory of the Russian Empire periodicals on accounting began to print out at the end of the nineteenth century.

All of them appeared primarily in capital cities, but economic life also raged on the periphery of the empire, which also caused the emergence of accounting periodicals there. So, the Accounting Department of the Kharkiv Branch of the Imperial Russian Technical Society began publishing a specialized magazine «Schetovodstvo i hozjajstvo» in 1912.

It was almost the only accounting magazine of such a high level, according to the contemporaries, which was published in the province. The head of the Kharkiv branch of the IRTS was M. F. von Dietmar in 1912. He also headed the publication of the magazine «Schetovodstvo $i$ hozjajstvo» (the body of the Accounting Department of the Kharkiv branch of the Imperial Russian Technical Society).

The first issue of the magazine was published in January 1912. The publisher and editor of the magazine, the head of the Kharkiv branch and the Accounting Department, M. F. von Dietmar, embodied the qualities of a well-known public figure, entrepreneur, and politician. Holding the 
post of chairman of the Kharkiv branch of RTS, M.F. von Dietmar made a report on the necessity to open the Accounting Department at the $\mathrm{KhB}$ IRTS at the meeting of the members general meeting of the branch on December 3, 1911. The main elements of this report are set out in the article by M.F. von Ditmar, published in the first issue of the magazine «Schetovodstvo i hozjajstvo» [21, p. 5-10]. This proposal was unanimously approved and adopted by the meeting, and the head of the society was offered to take over control of organization the department. Mykola Fedorovych took seriously and responsibly a new case, he researched the urgent problems and needs of the city of Kharkiv and the whole Southern region in relation to accounting in advance. Therefore, the first meeting of the Accounting Department took place on December 16, 1911, where it was unanimously decided to publish its own magazine, «which would highlight the tasks and aims of the Accounting Department» [22, p. 20]. All present on the meeting members of the society asked M. F. von Dietmar to take over editing and developing the pro-gram of the magazine of the Accounting Department.

As already mentioned, the first issue of the magazine of the Accounting De-partment of KhB IRTS «Schetovodstvo i hozjajstvo» was published on January 25, 1912. So, as we see, it was necessary for the Accounting Department headed by M. F. von-Dietmar to prepare and publish the first issue of the magazine for a little more than a month!

The authors placed a letter from the editorial office of «Nashi zadachi» in the first pages of the publication, having disclosed the task and aim or the magazine «Schetovodstvo i hozjajstvo» to the readers: «Our magazine should serve as a faithful reflection of the current state of the scientific and practical aspects of accounting in the application it to the most varied types of economy. Therefore, in our magazine attention will be drawn to the history of the development of accountancy knowledge, to various accounting systems and their application in accounting turnover of various sectors of economy, on various cases of accountancy practice in the field of the state institutions, zemstvo, urban, commercial and industrial, banking, agricultural, small credit institutions, various cooperatives, etc...

A living printed word can do a lot!...» [23, p. 3].

We can state that the program of the magazine was extremely wide and affected many theoretical and practical issues of accounting and its application in various fields of economic life of the country. 
On the cover of the magazine the authors placed the seal of the Kharkiv Branch of the Imperial Russian Technical Society with the inscription: «weight, measure, number». And M.F. von Dietmar emphasized in his report: «This motto of the Society is quite in line with the idea, tasks and goals of the future of accounting department of our society» [23, p. 4]. As we see, this statement became also the motto of the magazine «Schetovodstvo i hozjajstvo» - a printed body of the Accounting Department of the Kharkiv branch of the Imperial Russian Technical Society.

The magazine program below, in accordance with the tasks set forth, contained the following sections, the titles of which emphasized the coverage of a wide range of issues:

1) Laws and government orders; 2) History, theory and practice of accounting; 3) Articles on social, public and private issues of accounting and economy; 4) Teaching accounting; 5) Commercial life; 6) Finance, trade and industry; 7) Law and accounting; 8) Correspondence; 9) Analysis of reports of various industries and institutions; 10) Local and foreign chronicle; 11) Themes and tasks; 12) Questions and Answers; 13) Mixture and reference department; 14) Trial Chronicle; 15) Bibliography; 16) Announcements.

Starting up the publishing business, representatives of the Accounting Department planned to publish 1-3 issues per month, depending on the accumulated material for printing. The magazine was distributed only by subscription and did not enter any retail trade. The subscription price of «Schetovodstvo i hozjajstvo» for ordinary citizens for one year was 4 rubles and for members of the KhB IRTS - 2 rubles.

For the convenience of subscribers who did not live in Kharkiv, a subscription form was added to the first issue of the magazine. To cover some printing costs, it was decided to post various advertisements on the magazine's pages, but at a fixed price.

During the first year of its existence 15 issues of the magazine «Schetovodstvo i hozjajstvo» were prined out, the total volume of which was 490 pages. Unfortunately, at the current stage of the study we did not find information about the financial side of the magazine's publication in the first year of its existence: was the publication liquid or unprofitable?

In the following two years - 1913 and $1914-24$ issues of the magazine «Schetovodstvo i hozjajstvo» (twelve issues annually) were printed out, with a total volume of 821 pages (the numbering of pages during the twoyear period was cross-cutting). As we can see, the amount of information 


\section{Chapter «Historical sciences»}

contained in the magazines was almost unchanged from 1912 and during the next years of publication, the terms of the magazine publication and its subscription price remained unchanged, however, for the members of the Accounting Department the magazine was published free of charge. The terms for posting advertisements in the magazine were also not changed.

In our opinion, such a situation could not but affect the financial side of the magazine publication. The confirmation is found in the cash accounting report of the Accounting Department for 1913.

As it follows from the above-mentioned document, the proceeds of the magazine «Schetovodstvo i hozjajstvo» in 1913 was 2250 rubles and 50 kopecks, and expenses for the corresponding period - 3025 rubles and 28 kopecks Thus, the budget deficit of the publication amounted to 774 rubles and 78 kopecks, which was covered by profits from the First All-Russian Congress of Accountants of Mutual Credit Societies, which was organized and conducted in Kharkiv by the Accounting Department of the KhB IRTS [24, p. 34].

In 1914 all conditions for publication of the magazine remained unchanged, except for the timing of the issue: 1-2 times a month. In 1914 the proceeds from the publishing amounted to 556 rubles and 90 kopecks, and expenditures -1184 rubles and 28 kopecks. Again, the amount of expenditures more than doubled exceeded proceeds. In comparison with the previous year, expenditures decreased slightly more than twice (1184 rubles against 3025 rubles), but the income decreased four times during the same period (556 rubles against 2250 rubles) [25, p. 42].

The above amounts to a presumption that there was not a shortage of materials, ideas and facts, not a shortage of authors, but most of all, there was the unprofitableness of the publication that caused the magazine «Schetovodstvo i hozjajstvo» to cease to exist in 1914.

The analysis of the content of all magazines also speaks in favor of our hypothesis. So, in 191256 works of 23 authors were published in the fifteen issues of the magazine. Attention is drawn to the fact that a number of articles are contained in several issues of the magazine «Schetovodstvo i hozjajstvo»: the work of O. Bauer «Inventarizacija» was published with the continuation in seven issues of the magazine, and «Memorial i hronologicheskij zhurnal. K peresmotru nashogo torgovogo zakonodatel'stva» - in four issues; the article by Y. Levin «Torgovye knigi» - in three issues of the magazine «Schetovodstvo i hozjajstvo»; the 
works of G. Bek-Ter-Davydov «O buhgalterskom kontrole pravlenij bankov nad inogorodnimi otdelenijami» and $\mathrm{M}$. Ter-Davydov «O sebestoimosti produktov proizvodstva $\mathrm{v}$ promyshlennyh predprijatijah» - in two issues of the magazine, (incidentally, M. Ter-Davydov was a lecturer in accounting at Katerynoslavsk High School of Mining in 1901-1913) [26, p. 65], the work of P. Fomin «Prakticheskaja postanovka promyshlennogo obrazovanija». Even this short list shows the diversity of the subject matter of publications in accordance with a certain program of the magazine, their relevance on the one hand, and on the other - the systematic and regularity of the publication of the magazine «Schetovodstvo i hozjajstvo» and a wide range of its readers and subscribers. As we see, the problems raised in the abovementioned works, affect not only purely accounting issues (inventory, accounting control, trading books), but also trade legislation, industrial production and organization of industrial education.

From the analysis of the minutes of the Accounting Department meetings of the KhB IRTS, it was ascertained that in 1912 the members of the department were involved in the organization and holding of the First AllRussian Congress of Accountants of Mutual Credit Societies in Kharkiv. Therefore, it is not surprising that such issues were actively debated in the magazine. It is worth drawing attention to the works of L. Aronov «K predstojashhemu s'ezdu obshhestv vzaimnogo kredita (OVK)», «Rajonnyj s'ezd predstavitelej OVK», M. Yegorov «K predstojashhemu S'ezdu buhgalterov OVK», «Neskol'ko slov po voprosu o s'ezde buhgalterov OVK» and B. Brontman» K voprosu o prisjazhnih buhgalterah» (that issue was one of the most urgent at the congress).

During the second year of existence of the magazine «Schetovodstvo $i$ hozjajstvo» 41 works of 19 authors were published there. It seems positive that the names of new authors appeared alongside the well-known names of L. Aronov, O. Bauer, M. Popov, E. Levin. During the year there were also articles that continued in several issues of the magazine: the works of O. Bauer «Inventarizacija», M. Manusevich «K voprosu o formah otchetov v OVK», A. Sierikov «Postanovka prepodavanija kommercheskih nauk v kommercheskih zagranichnyh institutah»

The activity of the First All-Russian Congress of Accountants of Mutual Credit Societies, which was held in Kharkiv in February that year, became a widespread coverage of the magazine's pages: preparatory work, program of the congress, discussion of problematic issues, comments on the work 


\section{Chapter «Historical sciences»}

of sections, etc. Furthermore, in addition to the materials of the congress of accountants, a number of works about the activities of mutual credit societies were published in the magazines in 1913.

21 articles of 10 authors were published in the magazine «Schetovodstvo i hozjajstvo» in 1914. Moreover, along with the well-known names new authors Y. Borodin, prof. I. Ozerov, A. Sevruk published their works on the pages of the magazine. The peculiarity of that year's edition was that it was more than half of the magazine's numbers were double. What became the cause is not well known now, but perhaps it was the socio-political conditions in the country - the beginning of the First World War, and that caused a reduction in the financing of publishing activities, as well as a slight decrease in materials for publications.

The editorial board of the magazine could not stay away from political events in the world and in the state, therefore, analytical materials of the journalists on the financial and economic situation of Russia during that period were regularly published on the pages of the magazine «Schetovodstvo i hozjajstvo», alongside with professional articles: «Nasha promyshlennost' i vojna», «Mirovoj urozhaj i vojna», «Promyshlenniki i finansisty o momente», «Perevozka hlebnyh gruzov i vojna», «Jekonomicheskaja kon'junktura Serbii i vojna», «K voprosu ob jekonomicheskoj jemansipacii ot Germanii», «Peremeny v dvizhenii mirovoj torgovli», «Juzhno-russkaja promyshlennost' vo vremja vojny» and so on.

We have been found and analyzed all the numbers of the magazine «Schetovodstvo i hozjajstvo» for 1912-1914. According to the «Bibliografiya» [27, p. 334], the magazine ceased to exist in 1914, and this information confirms the validity of our statement. The identified and analyzed numbers of the magazine «Schetovodstvo i hozjajstvo» constitute a great bibliographic rarity at the present stage. For today, in addition to the magazines there are only early texts of some of the magazine issues have been preserved in the State Archives of Kharkiv region [28].

Looking through the articles on the pages of the magazine «Schetovodstvo i hozjajstvo» for the last year, we find indirect references to further plans of the editorial board, which did not intend to discontinue its activity. So, an article by Y. Zvenigorodsky «Ugolovnyj zakon i sindikaty» with the abstract «Prodolzhenie sleduet» was published in issue No. 6. Therefore, the publishers obviously had plans to continue publishing the magazine «Schetovodstvo i hozjajstvo», because there was no shortage of authors 


\section{Kushlakova Nadiya, Oleshko Petro}

and materials for publications. From our point of view, the only reasons that hampered the life of the magazine, as noted above, could be unprofitable publication and war.

The activation of the Aeronautics Department of the Kharkiv Branch of the Imperial Russian Technical Society during the second year of its existence had, along with other affairs, another important result - the branch began to issue its own printed body - the journal «Tjazhelee vozduha». At a meeting on July 27, 1911 the Council of KhB IRTS made a decision on the publication of the magazine and approved its program. On October 3, 1911 after the summer holidays the Society appealed to the Kharkiv governor with a letter No. 418, in which the respective petition was made.

After verifying the reliability of the editor of Hrihory Ludwihovich Okulich-Kozarin (he also served as secretary of the Kharkiv branch of IRTS), the Council of KhB IRTS received a certificate No. 10861 dated 10.10.1911 containing the permission «... to publish in Kharkiv a magazine titled «Tjazhelee vozduha»...» [29, p. 18]. Due to the bureaucratic obstacles in the approval of normative and legal or permit documents for a particular direction or type of activity of public and scientific associations during the investigated period the permission for publishing activity was received quickly enough - almost within one week! The decisive role in that case most likely had a number of factors: a) Kharkiv Branch of the Imperial Russian Technical Society had been successfully operating in Kharkiv for more than 30 years; b) aircraft became important and widely popular in the state, therefore, the pioneering initiatives associated with aeronautics were supported by the Kharkiv governor,who was a progressively thinking, respectable person; c) in the recent past (23.08.1911-14.09.1911) the Aeronautics Department of KhB IRTS successfully held the first aeronautic exhi-bition in Kharkov, which had a wide resonance not only in the south of the Russian Empire, but also in the entire state; d) the members of the Aeronautics Department did not raise doubts in police about the political confidence (personally, the responsible editor of the magazine) [29, p. 16-18].

The magazine «Tjazhelee vozduha» was planned to be issued as more material for publishing was accumulated, but not less than twice a month. The editorship of the magazine was located in the premises of the bureau of the Kharkiv branch of IRTS (Sumskaya St., 18), and the print was carried out in A. Zhmudskyi's printimg house «Utro». The magazine contained a wide range of information in its structure. The program included: «1. Government orders. 2. Advanced 


\section{Chapter «Historical sciences»}

articles on aviation issues. 3. Popular science articles. 4. Review of activity and chronicle of the Aeronautics Department. 5. Chronicle of aeronautics in Russia and abroad. 6. Letters to the editor. 7. Sports. 8. Bibliography. 9. Illustrations and polytypage for text. 10. Announcements» [29, p. 1].

In the first issue of the magazine the editorial board defined the purpose of its publication as follows: «...to serve a new cultural affair - the conscious conquest of the air for the benefit of the cultural development of the state, for the good of the people» [30, p. 4]. The stated tasks corresponded not only to the content but also to the price of the magazine, which was accessible to all interested persons: subscription for a year -5 rubles, for half a year 3 rubles, 1 copy -10 kopecks (for the members of the society all prices were practically twice lower). In order to organize a more productive activity of the printing authority of the Aeronautics Department for the next year, namely at the meeting of the Council of the KhB IRTS on September 20, 1912, it was decided «to appoint the second editor of the magazine "Tjazhelee vozduha» - the Vice-Chairman of the Aeronautics Department Valeriy Morokhovets, who will be edit the magazine in full» [29, p. 22], about which was reported to Kharkiv governor by letter of 5.10.1912.

In the course of the study, it was found that the magazine «Tjazhelee vozduha» was published during 1911-1913. However, even for a short period of its existence, it played an important role in spreading and popularizing aviation knowledge: it printed advanced articles on aviation, popular science articles, reviews of the activity and chronicle of the Aeronautics Department of the society, the chronicle of aeronautics in the Russian Empire and abroad.

\section{Conclusions}

Consequently, publishing activities of RTS branches in the industrialized regions of Ukraine made a significant contribution to the promotion of technical knowledge through the distribution of their printed publications, which became a valuable source in the history of domestic and world science and technology.

In «Zapiski» the branches printed not only information about its activities (minutes of the meetings of the Council and general meetings, lists of members, the composition of the Council, reports on activities, financial reports, etc.), and to a greater extent scientific and scientific and popular articles, which were oriented both on the representatives of the technical 
intelligentsia and on a wide range of readers. The subject of the published works covers a fairly wide range of scientific and technical knowledge: physics, mechanics, chemistry, metallurgy, mining and railway affairs, etc.

The magazine «Zapiski KhB IRTS» was the first and largest scientific and technical magazine with its versatility in the region. It had a high scientific and theoretical level, thanks to the participation of scientists and highly skilled engineers-practitioners in its publication.

In addition to «Zapiski», IRTS branches issued separate imprints of their members' works, books, brochures, catalogs, lists of members, reports, etc. In the absence of necessary and high-quality textbooks in the state, the activity of the Katerynoslavsk branch on the publication of educational literature for evening classes for workers was exceptional and in demand.

The cooperation of publishers of the magazines «Zapiski KB IRTS», «Novosti tehniki i promyshlennosti» and «Uspyekhi prokatnogo dyela» in the issues of the publication of scientific and technical literature became another confirmation of close communications between the representatives of the engineering and scientific elite of the industrial regions of Ukraine during the period under the study.

The periodicals of the Kharkiv branch of the IRTS are of great importance for the study of the history of the publishing industry of the scientific and technical societies and the history of accounting and aeronautics. In particular, the magazine «Schetovodstvo i hozjajstvo» existed only three years, but even for such a short period of time the authors of this edition did a lot to fulfill their main task of promoting «accounting knowledge» and to develop accounting in the state: the magazine became one of the best professional magazines, which was published on the periphery of the Russian Empire and contributed to the dissemination and popularization of accounting knowledge; famous scientists and accountancy practitioners of modern times L. Aronov, A. Bauer, M. Popov, P. Fomin, Y. Levin and others published their articles on the pages of the magazine; the published articles concerned topical problems of accounting, the theoretical and practical accounting issues were covered and discussed; the separate sections of the magazine contained purely practical articles: consultations and explanations on practical questions (questions and answers); explanations and comments on legislative acts, etc.

The conducted study does not exhaust the raised problem in connection with the activities of public scientific and technical associations in general, leaving a considerable space for further scientific research. 


\section{Chapter «Historical sciences»}

\section{References:}

1. Soboleva E. V. (1983). Organizatsiya nauki v poreformennoy Rossii. [Organization of science in post-reform Russia]. L.: Nauka, Leningr. otdel. 262 p. (in Russian)

2. Filippov N. G. (1976). Nauchno-tekhnicheskie obshchestva Rossii (1866-1917). [Scientific and technical societies of Russia (1866-1917)]. Ucheb. posobie. M., 214 p. (in Russian)

3. Ustav Imperatorskogo Russkogo tekhnicheskogo obshchestva. [Charter of the Imperial Russian Technical Society]. Zapiski Khar'kovskogo otdeleniya Imperatorskogo Russkogo tekhnicheskogo obshchestva. [Zapiski Kharkov Branch of the Imperial Russian Technical Society]. 1882, vol. 1. (in Russian)

4. Zapiski KhO IRTO. [Zapiski Kharkov Branch IRTS]. 1881, vol. 1. (in Russian)

5. Protokol obshchego i ocherednogo sobraniya 31 marta 1884 g. Zapiski KhO IRTO. [Zapiski Kharkov Branch IRTS]. 1885, vol. 2. (in Russian)

6. Protokol zasedaniya Soveta 20 aprelya 1885 g. Zapiski KhO IRTO. [Zapiski Kharkov Branch IRTS]. 1887, vol. 1, pp. 67-70. (in Russian)

7. Otchet o deyatel'nosti KhO IRTO za 1885-1886 g. Zapiski KhO IRTO. [Zapiski Kharkov Branch IRTS]. 1889, vol. 2. (in Russian)

8. Zapiski KhO IRTO. [Zapiski Kharkov Branch IRTS]. 1898, vol. 2. (in Russian)

9. Oglavlenie «Zapisok EORTO» za 1902-1908 g. Zapiski EO IRTO. [Zapiski Katerinoslavsk Branch IRTS]. 1909, no. 9-10. (in Russian)

10. Godovoy otchet otdeleniya za 1904 g. Zapiski EO IRTO. [Zapiski Katerinoslavsk Branch IRTS]. 1905, no. 3-4, pp. I-XXII. (in Russian)

11. Zhurnal zasedaniy 13 yanvarya 1905 g. Zapiski EO IRTO. [Zapiski Katerinoslavsk Branch IRTS]. 1905, no. 3-4, pp. XXVI. (in Russian)

12. Galitskiy V. S. (1906). Chteniya po mekhanike. [Readings on mechanics]. Ekaterinoslav. 44 p. (in Russian)

13. Galitskiy V. S. (1907). Chteniya po fizike. [Readings on physics]. Ekaterinoslav. 60 p. (in Russian)

14. Mal'tsev A. M. (1908). Zhelezo-betonnye sooruzheniya Ekaterininsk. zh. d. [Iron and concrete structures of Yekaterininskaya railway]. Ekaterinoslav. 184 p. (in Russian)

15. Vodosnabzhenie st. Sinel'nikovo Ekaterininsk. zh. d. i st. Sinel'nikovo K.-Kh.-Sevastopol'sk. zh. d. iz r. Dnepra. (1907). [Water supply of st. Sinelnikovo Yekaterininskaya railway and st. Sinelnikovo K.-Kh.-Sevastopolskaya railway from the Dnieper River]. Ekaterinoslav. 56 p. (in Russian)

16. Mal'tsev A. M. (1909). Ustroystvo i eksploatatsiya poley orosheniya $g$. Odessy, g. Kieva, g. Moskvy. [The arrangement and operation of irrigation fields in the city of Odessa, the city of Kiev, the city of Moscow]. Ekaterinoslav. 22 p. (in Russian)

17. Averkiev N. K voprosu o mekhanicheskoy ochistke stochnykh vod i spuske ikh v reku Dnepr po proektu P. F. Gorbacheva o kanalizatsii g. Ekaterinoslava. [Due to the issue of mechanical clarification of sewage waters and descent them into the river Dnipro under the project of P. Gorbachev on the sewerage of Yekaterinoslav]. Bez tit. 1.16 p. (in Russian)

18. Zapiski Ekaterinoslavskogo otdeleniya RTO. [Zapiski Katerinoslavsk Branch IRTS]. 1906, no. 1-2. (in Russian) 


\section{Kushlakova Nadiya, Oleshko Petro}

19. Zapiski Ekaterinoslavskogo otdeleniya RTO. [Zapiski Katerinoslavsk Branch IRTS]. 1907, no. 7-8. (in Russian)

20. Ot avtora. [From the author]. Uspekhi prokatnogo dela $v 1912 \mathrm{~g}$. [Success of the rolling mill in 1912]. Novocherkassk: Donskoy pechatnik, 1913. 138 p. (in Russian)

21. Ditmar N. F. fon. (1912). O neobkhodimosti organizatsii pri Khar'kovskom otdelenii Russkogo Tekhnicheskogo obshchestva schetovodnogo otdela. Ego zadachi i tseli. [On the need for an organization at the Kharkov branch of the Russian Technical Society of the accounting department. His tasks and goals]. Schetovodstvo $i$ khozyaystvo. [Accounting and Economy], no 1, pp. 5-10. (in Russian)

22. Otchet o deyatel'nosti Khar'kovskogo otdeleniya Imperatorsko-go Russkogo tekhnicheskogo obshchestva za 1912 g. [Report on the activities of the Kharkov department of the Imperial Russian Technical Society for 1912]. Khar'kov, 1913. 53 p. (in Russian)

23. Schetovodstvo i khozyaystvo. [Accounting and Economy]. 1912, no 1. (in Russian)

24. Otchet o deyatel'nosti Khar'kovskogo otdeleniya Imperatorskogo Russkogo tekhnicheskogo obshchestva za 1913 g. [Report on the activities of the Kharkov department of the Imperial Russian Technical Society for 1913]. Khar'kov, 1914. 58 p. (in Russian)

25. Otchet o deyatel'nosti Khar'kovskogo otdeleniya Imperatorsko-go Russkogo tekhnicheskogo obshchestva za 1914 g. [Report on the activities of the Kharkov department of the Imperial Russian Technical Society for 1914]. Khar'kov, 1916. 64 p. (in Russian)

26. Zapiski EVGU za 1924-1925: Yubileynyy vypusk. [Zapiski Katerinoslavsk Branch IRTS, 1924-1925]. 1926, no. 1. (in Russian)

27. Belyaeva L. N. (1960) Bibliografiya periodicheskikh izdaniy Rossii, 1901-1916 [Bibliography of Periodicals of Russia, 1901-1916] / Belyaeva L. N., Zinov'eva M. K., Nikiforov M. M.: v 4-kh tomakh. L.: [GPB], vol. 3. (in Russian)

28. DAKhO. F. 3, op. 285, d. 142. (in Russian)

29. DAKhO. F. 3, op. 285, d. 74. (in Russian)

30. Tyazhelee vozdukha. [Heavier than the Air]. 1911. № 1. (in Russian) 